\title{
aIIRC
}

\section{O DIREITO A CIDADES SUSTENTÁVEIS NA ORDEM JURÍDICA BRASILEIRA E O CAMINHO PARA A URBANIZAÇÃO RACIONAL}

The Right To Sustainable Cities In Brazilian Legal System And The Path To Rational Urbanization

\section{João Luis Nogueira Matias}

Universidade Federal do Ceará, Fortaleza, CE, Brasil

Lattes:http://lattes.cnpq.br/8192937377585273 Orcid: http://orcid.org/0000-0002-3873-702X

E-mail: joaoluisnm@uol.com.br

\section{Lucas Campos Jereissati}

Universidade Federal do Ceará, Fortaleza, CE, Brasil

Lattes:http://lattes.cnpq.br/1955937876650870 Orcid: https://orcid.org/0000-0002-7243-2684

E-mail: lucasverlaine@gmail.com

Trabalho enviado em 01 de julho de 2020 e aceito em 06 de novembro de 2021

\section{(c) (i)}

This work is licensed under a Creative Commons Attribution 4.0 International License. 


\section{RESUMO}

O artigo foca no conceito de cidades sustentáveis, como pressuposto para a compreensão do direito à cidades sustentáveis, instrumento para mitigar os efeitos do crescimento urbano descontrolado no Brasil. Parte-se da abordagem da disputa ideológica sobre o conceito de desenvolvimento sustentável e de sustentabilidade, para adotar a prevalência da proteção ao meio ambiente. Em seguida, a abordagem centra-se no conceito de cidades sustentáveis, analisando o seu conteúdo e os indicadores que permitem a sua caracterização, com as influências dos indicadores firmados por documentos internacionais. Após, verifica-se a definição do direito a cidades sustentáveis na ordem jurídica nacional. Conclui-se, ao final, que, apesar das dificuldades em sua implementação, o direito a cidades sustentáveis é instrumento que pode ser utilizado para a urbanização racional, direcionando este processo para a garantia do bem-estar da população e da equidade intergeracional. A pesquisa é qualitativa e bibliográfica, centrada em textos normativos e doutrina.

Palavras-Chaves: Direito a Cidade Sustentável - Desenvolvimento Urbano Sustentável - Direito Urbanístico - Direito Ambiental - Urbanização

\section{ABSTRACT}

The analysis focuses on the concept of sustainable cities as a prerequisite for understanding the right to sustainable cities, an instrument that can be used to mitigate the effects of uncontrolled urban growth in Brazil. It starts with the approach of the ideological dispute over the concept of sustanaible development and sustainability, to adopt the prevalence environment protection over the social and economic dimensions. Then, the approach focuses on the concept of sustainable cities, analyzing their content and the indicators that allow their characterization. Afterwards, the definition of the right to sustainable cities is verified in the brazilian legal system. It is concluded that, despite de difficulties in it's implementation, the right to sustainable cities is an instrument that can be used for rational urbanization, ensuring the well-being of the population and the intergenerational equity. The research is qualitative and bibliographic, centered on normative texts and doctrine.

Keywords: Right to Sustainable Cities - Sustainable Urban Development - Urban Law - Environment Law - Urbanization 


\section{INTRODUÇÃO}

O crescimento desordenado das regiões urbanas brasileiras tem provocado grandes danos de ordem ecológica, social e econômica, como segregação espacial, má-qualidade do ar e do solo urbano, aumento das desigualdades sociais, espraiamento, redução da biodiversidade, aumento do número de moradias precárias e irregulares, entre outros.

Este cenário tem despertado intenso debate sobre as suas causas, efeitos e propostas de redução dos danos acarretados. É na perspectiva de oferecer alternativa que possibilite a melhor organização dos espaços urbanos que se analisa o modelo das cidades sustentáveis, como instrumento para mitigar os efeitos negativos do crescimento desordenado.

O modelo é atrativo principalmente em decorrência de três fatores básicos: a) atuação em três dimensões interligadas (social, econômica e ambiental); b) intenso debate sobre a sua consistência e aplicação, inclusive em âmbito internacional, com menções em documentos da ONU-HABITAT e enquadramento como um dos Objetivos para o Desenvolvimento Sustentável da ONU (ODS-11) e c) adequação com o ordenamento jurídico brasileiro.

O objetivo do artigo é, portanto, contribuir para o debate acerca das cidades sustentáveis, procurando definir com maior precisão as balizas de sua conceituação, à luz da ordem jurídica nacional e a da doutrina, o que ensejará a melhor compreensão do direito a cidades sustentáveis. Qual o conteúdo necessário para uma cidade ser considerada sustentável? Os parâmetros fixados no plano internacional influenciam a compreensão do conceito? O direito a cidades sustentáveis é importante para a urbanização racional? Estas são as perguntas que se pretende responder ao longo do trabalho.

Antes da abordagem do núcleo central do artigo, como necessário pressuposto, impõem-se uma reflexão acerca dos conceitos de sustentabilidade e desenvolvimento sustentável, tema que ainda desperta discussões doutrinárias e que é vital para compreensão da sustentabilidade das urbes. Em seguida, será analisado o conceito de cidades sustentáveis, com a definição dos indicadores de sustentabilidade. Após, será analisada a adequação do conceito à ordem jurídica nacional, com a caracterização do direito a cidades sustentáveis, importante elemento para a urbanização racional . Ao final serão apresentadas as conclusões.

A pesquisa é qualitativa e bibliográfica, centrada em textos normativos e na doutrina. 


\section{A DISPUTA TERMINOLÓGICA E IDEOLÓGICA EM TORNO DAS NOÇÕES DE DESENVOLVIMENTO E SUSTENTABILIDADE}

Por bastante tempo, a ideia de desenvolvimento/crescimento econômico não incorporava aspectos como equidade e proteção ao meio ambiente. Cada uma dessas dimensões era considerada autônoma, não havendo maiores interações entre elas.

Durante a segunda metade da década de 1960, o debate sobre a escassez dos recursos naturais se intensifica e passa-se a discutir a possibilidade de um colapso social, ambiental e econômico. No estudo denominado Os Limites do Crescimento, de 1972, elaborado pelo Clube de Roma (um think tank internacional de análise do sistema global), fez-se o alerta de que vários tipos de recursos naturais - incluindo minérios utilizados na produção de bens de ampla circulação econômica - estariam esgotados em algumas décadas ${ }^{1}$.

Ainda no ano de 1972, a Organização das Nações Unidas (ONU) realizou a Conferência de Estocolmo sobre Meio Ambiente Humano, onde foi adotada a Declaração de Estocolmo² (1972, online), a qual dispõe acerca de vários princípios sobre a relação desenvolvimento/proteção ambiental. Entre os quais, os princípios da necessidade de preservação dos recursos naturais para as futuras gerações, da necessidade de produção de recursos vitais renováveis, da cautela com o uso dos recursos não renováveis e da aplicação do "[...] planejamento aos assentamentos humanos e à urbanização com vistas a evitar repercussões prejudiciais sobre o meio ambiente e a obter os máximos benefícios sociais, econômicos e ambientais para todos"(1972, online), entre tantos outros.

Já em 1983, a ONU cria a Comissão Mundial para o Meio Ambiente e o Desenvolvimento, também chamada de Comissão Brundtland, em homenagem à Gro Harlem Brundtland, ex-primeira ministra da Noruega e diretora do grupo. Eles tinham a tarefa de analisar as principais questões associadas ao binômio meio ambiente-desenvolvimento econômico e suas implicações, apresentando, ao fim, soluções inovadoras para os problemas encontrados.

\footnotetext{
${ }^{1}$ Sachs (2017, np), em comentário ao estudo, relata que, apesar de as previsões do documento não terem sido concretizadas, em razão de descobertas de novas reservas dos recursos naturais nele indicados, ainda não se sabia que os reais limites não eram aqueles relativos à quantidade de minérios, mas sim à capacidade de funcionamento dos ecossistemas, de absorção dos gases de efeito estufa e outros poluentes. Ou seja, a mensagem era de que o planeta é finito e tem limites.

${ }^{2}$ Disponível em: http://www.direitoshumanos.usp.br/index.php/Meio-Ambiente/declaracao-de-estocolmosobre-o-ambiente-humano.html. Acesso em: 6 out. 2018.
} 
O fruto do trabalho da Comissão Brundtland foi apresentado em 1987 e denominado de Nosso Futuro Comum (COMISSÃO MUNDIAL SOBRE MEIO AMBIENTE E DESENVOLVIMENTO, 1991). O documento trazia uma conexão entre crescimento econômico, necessidade da proteção ambiental e redução da pobreza mundial, que deveriam ser trabalhados de forma conjunta para o bem-estar da humanidade.

O relatório não fugiu do tratamento da questão urbana, ao afirmar a necessidade de melhorias de infraestrutura, serviços e moradias, especialmente nas cidades dos países em desenvolvimento, os quais têm poucas condições de fornecê-las, gerando um crescimento no número de assentamentos informais de condições insalubres; enquanto isso, as urbes dos países industrializados sofriam com degradação ambiental, infraestrutura decadente e descaracterização dos bairros, mas, como possuem recursos financeiros, a solução desses problemas dependeria de vontade social e política. $O$ referido estudo também destacou que a boa administração dos centros urbanos deveria levar em conta a descentralização administrativa e de recursos para as autoridades locais, que teriam melhores condições de avaliarem a situação de sua área (COMISSÃO MUNDIAL SOBRE MEIO AMBIENTE E DESENVOLVIMENTO, 1991, p.17-18). Além disso, afirmava que “[...] o desenvolvimento sustentável das cidades depende de uma cooperação mais estreita com as maiorias pobres urbanas, que são os verdadeiros construtores das cidades" (COMISSÃO MUNDIAL SOBRE MEIO AMBIENTE E DESENVOLVIMENTO, 1991, p.18).

A partir deste relatório, desenvolveu-se aquilo que seria conhecido, especialmente após a conferência Rio $92^{3}$, por desenvolvimento sustentável. Um novo paradigma de desenvolvimento que deveria atender "[...] as necessidades do presente sem comprometer a capacidade de as gerações futuras atenderem também às suas" (COMISSÃO MUNDIAL SOBRE MEIO AMBIENTE E DESENVOLVIMENTO, 1991, p.9), conformando, assim, a ideia de equidade intergeracional ${ }^{4}$.

Após a Conferência das Nações Unidas sobre o Meio Ambiente e o Desenvolvimento (Rio92), o conceito de desenvolvimento sustentável passou a ser lido por boa parte dos atores globais como um equilíbrio entre seus três eixos ${ }^{5}$ (econômico, social e ambiental), que teriam igual importância, não resolvendo, desta forma, a questão da amplitude da ideia, o que levou a uma intensa disputa ideológica a respeito de seu conteúdo.

\footnotetext{
${ }^{3}$ Também conhecida por Eco-92.

${ }^{4}$ Esta noção de desenvolvimento sustentável também leva a ideia de equidade intrageracional, havendo, também, a necessidade de uma melhor distribuição de recursos entre as gerações já existentes.

${ }^{5}$ Importante trazer o fato de que autores como Veiga (2015) e Freitas (2016) entendem que o desenvolvimento sustentável possui mais dimensões do que as aqui trazidas.
} 
Quanto a essa questão, Caradonna (2014, p.6-7) afirma que o termo "desenvolvimento sustentável" é tão vago que está sujeito à exploração e "greenwashing", isto é, a prática de entidades adotarem discurso ambientalmente correto sem realmente assim atuarem, apenas visando valorizar seus produtos e ações para um novo nicho de mercado.

Leff $(2005$, p.23), em visão crítica, defende que o discurso prevalente acerca do desenvolvimento sustentável visa apenas manter políticas neoliberais em funcionamento, sem atentar para os limites da natureza, o que tende a levar a uma grande catástrofe ambiental, motivada pela busca por desenvolvimento econômico ilimitado.

Diante da fragilidade do conceito, que não privilegia a proteção ao meio ambiente e a manutenção da equidade intergeracional, Bosselman (2015) e Caradonna (2014) partem da noção clássica de sustentabilidade para chegarem a um conceito de desenvolvimento sustentável que realmente represente a devida preocupação com suas três dimensões, sendo, assim, a sustentabilidade um fio condutor para este conceito.

Desta forma, Bosselman (2015, p.41) informa que a concepção clássica de sustentabilidade, surgida ainda nos tempos medievais, é a de "[...] viver da produção, não da matéria", ou seja, de "viver dentro dos limites dos sistemas ecológicos", sem exauri-los e mantendo sua integridade.

Caradonna (2014, p.7-8), coadunando com Bosselman, afirma que o termo sustentabilidade surge da palavra latina "sustinere", cujo significado é manter, suportar, restringir. Segundo Caradonna (2014, p.7-8), quase todas as definições existentes de sustentabilidade enfatizam um ponto de vista ecológico, ou seja, a necessidade de os seres humanos viverem em harmonia com o meio natural.

Desta forma, a ideia de sustentabilidade está ligada à manutenção do equilíbrio dos sistemas ecológicos, de sua capacidade de regeneração e de absorção de impactos negativos. Em outras palavras, o sentido do termo sustentabilidade é o de sustentabilidade ecológica, que deve ser um efetivo limite para a ação humana e para o crescimento econômico.

Essa noção deveria, então, ser utilizada como fio condutor para interpretação do conceito de desenvolvimento sustentável, como expõe Bosselman (2015, p.42-43), ao afirmar que a essência desta ideia é ecológica, sendo este o fator mais relevante:

A percepção dos fatores ambiental, econômico e social como sendo igualmente importantes para o desenvolvimento sustentável é, indiscutivelmente, o maior equívoco do desenvolvimento sustentável e o maior obstáculo para se alcançar a justiça socioeconômica. 
Neste mesmo sentido, Veiga $(2015$, p.21-22, 46) afirma que a fórmula de tratar as três dimensões citadas em pé de igualdade com o desenvolvimento criou o subterfúgio de dizer que a ideia de sustentabilidade estaria presente em apenas uma dessas dimensões, quando, na verdade, o termo, ao qualificar a noção de desenvolvimento, sempre apresentou a noção de uma convivência harmônica da humanidade com a biosfera, de modo a evitar os colapsos propagados nos anos 70 .

Ante essa disputa ideológica, tem início, de acordo com Bosselman (2015, p.47), a concorrência entre duas correntes: a da sustentabilidade forte (ecologista, crítica do crescimento ilimitado) e a da sustentabilidade fraca (colocando em pé de igualdade a justiça social, prosperidade econômica e sustentabilidade ambiental, onde a troca entre os capitais destas dimensões deveria gerar um valor constante, não importando qual dos eixos preponderasse).

Mesmo ante a referida disputa, Bosselmann (2015, p. 48) ensina que a preponderância da sustentabilidade ecológica (sustentabilidade forte) não foi perdida, estando implícita no Relatório Brundtland, na Declaração do Rio, de 1992, e em tantos outros documentos internacionais relacionados ao meio ambiente, afirmando que a ideia de desenvolvimento sustentável só poderá alcançar sua capacidade normativa se levar em conta a ideia de sustentabilidade ecológica.

Concordando com a necessidade da preponderância sustentabilidade forte, Rees e Wackernagel (1996, p. 224-225) afirmam que, apesar das melhorias tecnológicas e econômicas, a humanidade continua em um estágio de dependência da produtividade e serviços de suporte de vida da ecoesfera, que forneceria recursos e fluxos (formas de "capital natural") para o processo econômico. Assim, nenhum desenvolvimento é sustentável se depende do esgotamento contínuo do capital natural.

Desta forma, Rees e Wackernagel (1996, p. 225), em defesa da sustentabilidade forte, sustentam que uma economia só seria sustentável se passasse de uma geração para outra um estoque de capital natural não inferior ao herdado pela geração anterior.

Para os fins aqui propostos, deve prevalecer a concepção de sustentabilidade forte como condutora do conceito de desenvolvimento sustentável, por ser a que possui melhores condições de garantir a justiça intergeracional e preservação das condições de vida, as disposições éticas mais marcantes na noção de desenvolvimento sustentável.

Claramente, havendo ofensa às capacidades de regeneração e absorção de impacto dos sistemas ecológicos do planeta, dificilmente será viável algum desenvolvimento econômico ou social durável, especialmente levando em conta o princípio da justiça intergeracional, que deve garantir às 
gerações futuras o acesso, pelo menos, à mesma quantidade de recursos naturais das gerações passadas.

Resta, por fim, afirmar que tanto a sustentabilidade quanto o próprio desenvolvimento sustentável são princípios jurídicos do direito ambiental internacional, orientando a criação de diversos documentos relativos à proteção ambiental internacional e ao próprio exercício das atividades econômicas e sociais.

Neste ponto, segundo Bosselman (2015, p. 80-81), o desenvolvimento sustentável está presente em várias declarações internacionais (como a declaração do Rio, seu Plano de Implementação, e Declaração de Joanesburgo), e até mesmo foi invocado em uma decisão da Corte Internacional de Justiça.

Barral (2012, p.393) afirma que o fato do princípio do desenvolvimento sustentável se apresentar, basicamente, em documentos de soft law não retira a sua normatividade, apenas aumentaria a margem de apreciação por parte das nações participantes destas declarações. Para ela (2021, p.385), o soft law seria muito brando para que obrigasse as nações a se desenvolverem de forma sustentável, mas faria, pelo menos, o papel de obrigar os Estados a promoverem e tentarem alcançar o desenvolvimento sustentável.

Assim, tem-se por desenvolvimento sustentável aquele que possui três dimensões: a econômica, social e ecológica, sendo esta última uma condição/limite para a implementação e atuação das demais, pois, não havendo a proteção ambiental efetiva, com a manutenção do fluxo de recursos naturais, a vida no planeta estaria ameaçada, bem como qualquer possibilidade de equidade intergeracional.

Firmados tais conceitos, importantes para a compreensão de contornos mais precisos acerca das cidades sustentáveis, passa-se à análise de como elas podem atenuar a crise urbana.

\section{AS CIDADES SUSTENTÁVEIS COMO CAMINHO PARA A MITIGAÇÃO DA CRISE URBANA}

As cidades são os centros de habitação da maior parte da população mundial contemporaneamente e continuam a crescer em rápida proporção. Apesar de bastante diferentes entre si, via de regra, apresentam certas características comuns.

Sachs (2017, np.), por exemplo, traz algumas condições especificadoras das cidades: 1) existência alta concentração populacional; 2) economia voltada essencialmente para os setores da indústria e dos serviços; 3) são zonas de relativa produtividade econômica, sendo a produção média das pessoas da zona urbana duas ou três vezes a das pessoas das zonas rurais de um país; 4) são centros de atividades inovadoras, com marcante presença do setor tecnológico e de ensino superior; 5) são, 
geralmente, grandes centros de comércio; 6) as grandes cidades, geralmente, estão perto do litoral ou têm acesso a ele; 7) são, usualmente, centros de grande desigualdade social; 8) são lugares de intenso crescimento populacional; 9) têm a produtividade favorecida pelos grandes mercados que oferecem; 10) enfrentam grandes problemas com externalidades urbanas, como congestionamentos, poluição, degradação ambiental, entre outros.

As características referidas mostram alguns dos imensos desafios presentes nos centros urbanos. Muitos destes, no entanto, também representam efetivas oportunidades para a busca pelo desenvolvimento sustentável e a melhoria da qualidade de vida da sua população.

Rees e Wackernagel (1996, p. 242), por exemplo, afirmam que, mesmo diante de grandes desafios, as cidades são capazes de ajudar no processo de desenvolvimento sustentável global de várias formas. Entre elas, destacam-se o fato de requererem menos custo per capita para instalação de infraestruturas como esgoto sanitário e tratamento de água; maiores possibilidades para reciclagem de produtos; menor uso de solo, visto a grande densidade populacional dos centros urbanos; e redução do uso de combustíveis fósseis utilizados por automóveis, pois há a possibilidade de deslocamentos por transporte público, bicicletas e caminhadas (RESS, WACKERNAGEL, 1996, p.242).

A fim de que possam atuar como instrumento para a superação da crise urbana, importa conceituar o que são as cidades sustentáveis e definir quais os seus indicadores de sustentabilidade mais adequados.

3.1. O conceito de cidades sustentáveis como pressuposto para a mitigação da crise urbana

Definir cidades sustentáveis não é uma tarefa fácil. Como exposto, os conceitos de desenvolvimento sustentável e sustentabilidade são alvo de forte disputa política e ideológica, e isto se reflete, também, na construção do conceito de cidades sustentáveis.

Essa expressão, cidades sustentáveis, inclusive, é alvo de críticas, como a de Mello (2017, p. 451-452), ao afirmar que esta denominação é vinculada, basicamente, a questões ambientais e econômicas, não representando, assim, um caráter de equidade, voltado para aspectos clássicos da agenda urbana. Este discurso também é criticado por representar apenas uma forma de manutenção do sistema hegemônico, garantindo a alocação de recursos naturais necessários para o acumulo de capital (LIMONAD, 2010, p.8).

Entretanto, poucas nações questionam a necessidade de alcançar a sustentabilidade dos centros urbanos do planeta, não havendo, todavia, um consenso acerca do conteúdo necessário para uma cidade ser considerada sustentável. 
Satterthwaite (1997, p. 1668) expõe, ademais, que há um amplo espectro de objetivos sociais, econômicos, políticos, culturais e institucionais que afirmam integrar o conteúdo do desenvolvimento sustentável, de forma a boa parte dos governos e agências internacionais caracterizarem algumas de suas ações como contributivas para o alcance do desenvolvimento urbano sustentável, mesmo que busquem objetivos que, quando atingidos em determinado setor ou localização, representem um ou mais passos atrás na implementação do desenvolvimento sustentável de forma mais ampla. Ou seja, não há uma integração de ações visando a mesma finalidade: o desenvolvimento sustentável. Muitas vezes, as intervenções são isoladas, sem atentar para um quadro macro de integração, mais completo e complexo, objetivando apenas uma das dimensões do desenvolvimento sustentável.

Além disso, como explica Porras (2009, p.576-578), as cidades são muito diversas entre si, então também apresentam políticas para o desenvolvimento sustentável bastante diferentes, onde, a depender do local, há prevalência de certas prioridades em detrimento de outras. De acordo com a autora, cada centro urbano tem necessidades e vocações distintas, especialmente quando se trata de cidades localizadas em países com níveis de desenvolvimento econômico e social diferentes (PORRAS, 2009, p.576-578). Portanto, deve-se esperar, inclusive, uma distinção de prioridades entre as políticas para desenvolvimento urbano sustentável das cidades ricas dos países do norte para as das cidades pobres dos países do sul ${ }^{6}$.

Acselrad (1999), por sua vez, ao dissertar a respeito dos discursos de sustentabilidade urbana, afirma que houve uma "ambientalização" do discurso sobre políticas urbanas e, ao mesmo tempo, um aumento do tratamento da questão ambiental no discurso das políticas urbanas. Ou seja, o discurso a respeito da sustentabilidade dos centros urbanos parte tanto da perspectiva ambiental quanto é incluído dentro do debate acerca de políticas urbanas.

Continuando, Acselrad (1999, p.81-85) faz, então, uma classificação das matrizes discursivas da sustentabilidade urbana, utilizando a seguinte divisão: 1) representação técnico-material da cidade, que é subdividida em modelo da racionalidade ecoenergética e modelo do equilíbrio metabólico. Neste modelo a cidade é vista como uma continuidade de material e de fluxos, ou seja, em sua perspectiva material, onde a sustentabilidade dependeria de redução de gastos de energia, consumo e recursos naturais, o que poderia reduzir a dimensão política do espaço urbano; 2) cidade como

$6 \quad$ Neste ponto, quanto à disparidade entre cidades ricas do norte e pobres do sul, Costa $(1999$, p. 59) afirma que as cidades dos países industrializados, apesar da grande desigualdade, apresentam bons níveis de acesso à moradia, serviços públicos e outros benefícios providos pelo Estado de bem-estar social, não sendo mais um objeto de demanda como ocorre nas cidades do sul. 
espaço da "qualidade de vida", subdividida nos modelos da pureza, cidadania e patrimônio. Neste caso a cidade seria vista como um espaço de externalidades negativas (poluição, dejetos etc.), que seriam solucionadas com o fomento de direitos para os habitantes. Também seria possível equacionar esse modelo com a ecoeficiência, ou seja, o discurso ambiental da eficiência seria trazido para dentro da discussão acerca da qualidade de vida; 3) a reconstituição da legitimidade das políticas urbanas. Aqui, a insustentabilidade urbana seria decorrente da falta de capacidade das políticas urbanas de fornecerem a quantidade e a qualidade de serviços urbanos demandados pela sociedade, o que poderia gerar instabilidade nas bases de legitimidade daqueles responsáveis pela política urbana. Esse desequilíbrio no fornecimento de serviços acabaria por ocasionar desigualdade e degradação ambiental, ou seja, a questão ambiental também estaria envolvida.

Assim, esses modelos discursivos acabam por abarcar situações e circunstâncias semelhantes (qualidade de vida, proteção ambiental, eficiência no uso de recursos etc.), mas com intensidades diferentes no que toca ao aspecto técnico, político e social, em seus vieses negativos e positivos.

Importante lembrar, como informa Costa (1999, p.55-56), que há certa contradição e incompatibilidade entre os termos urbano e ambiental, de forma que, a priori, há conflitos de difícil solução na ideia de desenvolvimento sustentável e cidades sustentáveis. Segundo Costa (1999, p. 5556), essa disputa se deve ao fato de as duas agendas terem surgido em áreas diferentes do conhecimento, havendo, todavia, certa convergência na atualidade, em face da noção de desenvolvimento sustentável.

Neste sentido, o discurso acerca da sustentabilidade urbana e do desenvolvimento sustentável/cidades sustentáveis parece realmente ter dado confluência a questões urbanas e ambientais, o que vêm ocorrendo com mais intensidade desde a década de 1990, ganhando força com o passar dos anos, como demonstram dois importantes e recentes documentos internacionais: os Objetivos para o Desenvolvimento Sustentável (ODS) da Agenda 2030 (2015), onde foi instituído o ODS-11, sobre cidades e comunidades sustentáveis, e a Nova Agenda Urbana (2016), elaborada durante a terceira Conferência da ONU sobre Habitação e Desenvolvimento Urbano Sustentável.

Nestes documentos, é marcante a confluência da agenda ambiental com a urbana, fazendose presentes aspectos como enfrentamento às mudanças climáticas, redução do impacto negativo das cidades no meio ambiente natural, qualidade do ar urbano, garantia de acesso a espaços verdes públicos e a transportes sustentáveis nas cidades, habitação digna, acesso à educação, erradicação da pobreza, entre tantas outras pautas que tangenciam aspectos do meio ambiente artificial e natural. 
Fica evidente, ante aos instrumentos expostos, a presença de uma comunhão entre as agendas urbana e ambiental, com ponto de partida nas questões relativas à primeira agenda. Os dois documentos citados trazem o discurso de uma agenda urbana "esverdeada", unindo à problemática urbana questões ambientais referentes às particularidades e aos desafios enfrentados pelos centros urbanos.

Assim, não parece excesso afirmar que o modelo de cidades sustentáveis (desenvolvimento urbano sustentável) surge como uma forma de dar certa convergência a duas agendas (urbana e ambiental) que por muito tempo tendiam mais à separação que à união. Contudo, não se pode desprezar a possibilidade da apropriação do discurso da sustentabilidade urbana para fins outros que não a harmonização de agendas. Impõe-se, desta forma, uma definição mais concisa de cidades sustentáveis, em sintonia com a noção de desenvolvimento sustentável.

Genericamente, a partir da definição proposta por Sachs (2017, np), cidades sustentáveis são aquelas que, obedecendo ao princípio da equidade intergeracional, promovem atividades econômicas produtivas, são social e politicamente inclusivas e ambientalmente sustentáveis, sendo esta última dimensão limitadora para as demais.

Não significa, no entanto, que a dimensão ambiental sempre preponderará ante as demais, ou que haja uma "intocabilidade" do meio ambiente natural. Significa, apenas, que as outras dimensões devem respeitar os limites ecológicos, até mesmo como forma de garantir a equidade intergeracional, elemento chave da noção de desenvolvimento sustentável, como expõe Veiga (2015, p.10).

Deve ser levado em conta também, nas palavras de Rees e Wackernagel (1996, p. 236), que nenhuma cidade pode alcançar a sustentabilidade por si, pois os centros urbanos, através do comércio e dos ciclos biogeoquímicos naturais "apropriam-se" das funções de produção ecológica e de suporte à vida de regiões distantes do mundo todo.

Tem-se, assim, um conceito bastante genérico de cidades sustentáveis, com margem para escolha de prioridades, mas, também que fixa uma base de atuação mais sólida, a da necessidade da sustentabilidade ecológica, de respeito aos limites ambientais. Não significa, porém, que as dimensões econômica e social não apresentem relevância, mas que estas devem atuar dentro dos limites da integridade ecológica.

Haveria, no entanto, algum conteúdo mínimo do que seria uma cidade sustentável? Alguns indicadores são úteis para a definição deste conteúdo mínimo. Passa-se a examiná-los.

3.2 Indicadores de sustentabilidade e o conteúdo mínimo do conceito de cidades sustentáveis 
Como visto, alguns indicadores são úteis para a definição de um conteúdo mínimo para o conceito de cidades sustentáveis, e várias instituições já adentraram neste mérito.

Pode-se apontar os indicadores decorrentes do Objetivo para o Desenvolvimento Sustentável de número 11, da Agenda 2030, da Organização das Nações Unidas; os expostos pela Fundação Europeia para a Melhoria das Condições de Vida e de Trabalho, agência da União Europeia elaboradora de indicadores de sustentabilidade urbanos baseados na Carta de Aalborg, adotada na Primeira Conferência Europeia Sobre Cidades Sustentáveis; e os indicados pelo Instituto de Pesquisa Econômica Aplicada (IPEA) para a elaboração do Relatório Brasileiro para à Habitat III, conferência da ONU para assentamentos humanos e cidades sustentáveis. Estes indicadores são representativos do que expressa o referido conceito, no âmbito global, europeu (norte) e brasileiro (sul), o que justifica a sua análise.

Importante lembrar que os indicadores têm limitações e também sofrem críticas, como as feitas por Kaika (2017), que afirma que os indicadores, muitas vezes, são feitos através de consensos e não representam, por isso, as verdadeiras dificuldades enfrentadas pelas cidades, muitas vezes não conseguindo refletir as complexas realidades urbanas. Contudo, não há dúvida de que podem ser utilizados com a finalidade de uma maior especificação das necessidades dos centros urbanos para o desenvolvimento sustentável.

A ONU, ao estabelecer as cidades sustentáveis, inclusivas, seguras e resilientes como um Objetivo para o Desenvolvimento Sustentável (ODS 11), trouxe os seguintes indicadores: 1) proporção de população urbana vivendo em favelas, assentamentos informais ou habitações inadequadas; 2) proporção da população que tem acesso a transporte público, por sexo, idade e deficiência; 3) relação da taxa de consumo de terra em relação à taxa de crescimento populacional; 4) proporção de cidades com estrutura para participação direta da sociedade civil, de forma democrática e regular, no planejamento urbano; 5) total de gasto (público e privado) per capita na preservação, proteção e conservação do patrimônio cultural e natural, por tipo de patrimônio, nível de governo, tipo de gasto e tipo de financiamento privado; 6) número de mortos, desaparecidos e afetados por desastres por 100.000 habitantes; 7) perda econômica direta em relação ao PIB relacionada a desastres; 8) proporção de resíduos sólidos coletados e devidamente descartados em relação ao total de resíduos sólidos gerados, por cidades; 9) níveis médios anuais de emissão de partículas finas; 10) proporção média de áreas construídas que são espaços abertos de uso público de todos, por sexo, idade e deficiência; 11) proporção de pessoas vítimas de violência sexual ou física, por sexo, idade e deficiência, nos últimos 12 meses; 12 ) proporção da população que vive em cidades que implementam 
planos de desenvolvimento urbano e regional, integrando projeções populacionais e necessidades de recursos, por tamanho da cidade; 13) proporção de governos locais que adotam e implementam estratégias locais de redução do risco de desastres em consonância com o Marco de Sendai para a Redução do Risco de Desastres 2015-2030; 14) número de países com estratégias nacionais e locais de redução do risco de desastres; 15) proporção de suporte financeiro para os países menos desenvolvidos que é alocado para a construção e adaptação de edifícios sustentáveis, resilientes e eficientes em recursos, utilizando materiais locais.

A Fundação Europeia para a Melhoria das Condições de Vida e de Trabalho, por sua vez, elaborou 16 indicadores de sustentabilidade urbana e sua forma de aferição (European Commissions DG Environment by the Science Communication Unit, 2018, p.19-20), que estão relacionados com os seguintes temas: 1) aquecimento global (quantidade de emissões de gases de efeito estufa); b) qualidade do ar (número de dias por ano em que os níveis seguros de ar são ultrapassados e o trânsito é parado); c) acidificação do solo (depósito de dióxido de enxofre, dióxido de nitrogênio e/ou amônia por hectare); d) toxicificação do ecossistema (presença de certas substâncias tóxicas em determinadas quantidades no ambiente); e) mobilidade urbana (número total de viagens por carro privado e sua duração em comparação ao número de viagens de transporte coletivo e sua duração); f) manejo de resíduos (toneladas de resíduos produzidos por habitantes por ano); g) Consumo de energia (quantidade de óleo-equivalente por habitante por ano) ; h) consumo de água (consumo de água por habitante, excetuando alguns fatores); i) incômodo (referente à quantidade de população afetada por poluição sonora, visual e por odor); j) justiça social (Porcentagem da população afetada pela pobreza, desemprego, falta de acesso à educação, informação, treinamento e lazer); I) qualidade da moradia (percentual da população afetada por falta de moradia ou que habita ambientes degradados/insalubres); $m$ ) segurança urbana (percentagem da população afetada seriamente por crimes e acidentes de trânsito; n) economia urbana sustentável (Renda individual total na cidade menos: déficit fiscal da cidade, despesas ambientais e danos à poluição por habitante por ano); o) verde/patrimônio cultural e espaços públicos (porcentagem de áreas verdes, públicas e de patrimônio local necessitada de reparos); p) participação popular (Percentagem total da população que participa nas eleições locais ou como membros ativos em associações para a melhoria urbana e qualidade de vida); e q) "sustentabilidade única" (a ser elaborador e identificado por cada centro urbano. Deve representar o grau em que fatores ou eventos únicos levam à sustentabilidade urbana em suas dimensões ambientais, sociais e econômicas). 
Quanto aos indicadores elaborados pelo $\operatorname{lpea}^{7}$ (on-line), quando da preparação da participação brasileira para a Habitat III, estes foram divididos em 7 eixos, em um total de 80 indicadores. Segundo a própria instituição (IPEA, 2016, p.14), a escolha destes indicadores representa não apenas os propostos de maneira geral pela ONU, ou os conhecimentos próprios do Ipea, mas resultaram "dos debates sobre qual informação melhor representa o Brasil visto pelos brasileiros". Devido a esse extenso rol, serão apresentados, aqui, apenas os eixos trabalhados pela instituição, com suas variáveis.

Os sete eixos trabalhados pelo Ipea foram: a) questões demográficas, com variáveis referentes a gênero, necessidade dos jovens e idosos, velocidade de urbanização e relação urbanorural; b) planejamento urbano e territorial, com variáveis sobre planejamento e projeto urbano sustentável; gestão da terra, inclusive espraiamento urbano; produção de alimentos na área urbana e periurbana; desafios da mobilidade urbana; e capacidade técnica para planejar e gerenciar cidades; c) meio ambiente e urbanização, com variáveis referentes a mudanças climáticas; risco de desastres; congestionamentos e poluição do ar; d) governança pública e legislação, com variáveis sobre legislação urbana; descentralização e fortalecimento das autoridades locais; participação e os direitos humanos no desenvolvimento urbano; segurança urbana e inclusão e equidade social; e) economia urbana, com variáveis sobre financiamento local/municipal; acesso ao financiamento habitacional; desenvolvimento econômico local; empregos e meios de vida decentes e integração da economia urbana na política nacional de desenvolvimento; f) habitação e serviços básicos, com variáveis sobre melhoramentos de favelas e prevenção de favelização; acesso à habitação adequada; garantia de acesso ao serviço de água potável; garantia de acesso ao serviço de esgotamento sanitário e à drenagem urbana; acesso a energias domésticas limpas; acesso aos meios de transportes sustentáveis; g) indicadores de referência ONU-Habitat.

Neste último item, o Ipea somou os indicadores mais específicos referentes ao território brasileiro a outros utilizados pela Agência da ONU para Assentamentos Humanos, a ONU-Habitat, que consistem em percentual de pessoas vivendo em favelas; percentual da população urbana com acesso a moradia adequada; percentual de pessoas vivendo em áreas urbanas com acesso à água potável; percentual de pessoas com acesso a esgotamento sanitário adequado; percentual de pessoas em áreas urbanas com acesso à coleta regular de resíduos sólidos; percentual de pessoas vivendo em áreas com

Disponível em: http://www.participa.br/habitat/habitat-iii-participa-brasil/indicadores/indicadoresbrasileiros-habitat-iii. Acesso em: 15 jun. 2019. 
acesso a energias domésticas limpas; percentual de pessoas vivendo em áreas com acesso ao transporte público; e nível de descentralização efetiva para o desenvolvimento urbano sustentável através de vários tipos de metragens, como percentual de despesas de autoridades locais financiadas por arrecadação local.

Uma análise comparativa entre as instituições aqui trazidas demonstra a preponderância quantitativa para questões sociais nos indicadores brasileiros, a maior preocupação com a sustentabilidade ecológica nos indicadores da Fundação Europeia para a Melhoria das Condições de Vida e de Trabalho, e um maior equilíbrio entre essas dimensões nos indicadores do ODS 11 , elaborados pela ONU.

Essas distintas perspectivas decorrem das disparidades existentes entre as cidades do hemisfério norte e as do hemisfério sul e aos focos de desenvolvimento sustentável de cada um. No entanto, há similaridades nos indicadores levantados pelas três instituições, como a preocupação com mudanças climáticas, poluição atmosférica, destinos dos resíduos sólidos e reciclagem, participação democrática, moradia digna, segurança urbana e transporte público de qualidade. Havendo, sim, nesta pequena amostragem, indicadores de conteúdo mínimo caracterizadores do que é tido por relevante para a caracterização do desenvolvimento urbano sustentável, abarcando todas as clássicas dimensões: social, ambiental/ecológica e econômica.

Mas deve-se ter em mente que a conformação positiva desses indicadores não torna uma cidade sustentável per si, pois cada cidade apresenta particularidades e necessidades específicas, além de que as trocas próprias da globalização fazem com que haja impactos exteriores causados pelos centros urbanos, ocasionando dependências externas de sustentabilidade. Servem, no entanto, de norte para uma avaliação mais complexa, a ser contextualizada e elaborada de acordo com as necessidades e especificidades de cada centro urbano. As cidades sustentáveis seriam, desta forma, não um fim, mas um caminho a ser galgado, visando uma maior equidade (intra e intergeracional) e crescimento econômico de baixo impacto, respeitando e protegendo os processos ecológicos fundamentais.

Assim, expostos alguns dos principais tópicos a respeito do conceito de cidades sustentáveis, parte-se para o debate acerca do direito a cidades sustentáveis no âmbito do ordenamento jurídico nacional. 


\section{O DIREITO A CIDADES SUSTENTÁVEIS COMO DIRETRIZ CHAVE DO DESENVOLVIMENTO URBANO BRASILEIRO}

Antes de abordar diretamente a questão das cidades sustentáveis no ordenamento jurídico nacional, faz-se relevante trazer à tona o contexto do surgimento do debate acerca do tema e a sua positivação no país.

O direito à cidade sustentável é previsto, expressamente, na ordem jurídica brasileira, como uma diretriz geral de politica urbana nacional, presente no art. $2^{\circ}$, I, do Estatuto da Cidade (Lei 10.257/2001), cujo objetivo é, entre outras disposições, estabelecer diretrizes gerais para política urbana, regulamentando os art.182 e 183 da Constituição Federal.

A tramitação desta lei durou 12 anos (1989-2001), devido aos longos embates ocorridos

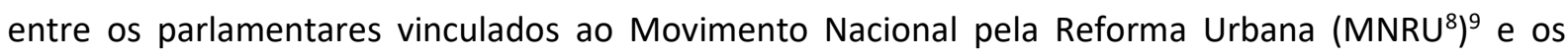
ligados ao empresariado urbano, proprietários de terras e setores mais conservadores, que, inicialmente, viam o Estatuto da Cidade como uma ameaça (BASSUL, 2004).

Neste ponto, é importante informar que, na redação original do projeto de lei que viria a se tornar o Estatuto da Cidade, havia a previsão da garantia do direito à cidade, entendida como "o conjunto de medidas que promovam a melhoria da qualidade de vida, mediante a adequada ordenação do espaço urbano e a fruição dos bens, serviços e equipamentos comunitários por todos os habitantes da cidade" (BRASIL, 1990).

Este termo, direito à cidade, advém da obra homônima, lançada em 1968, de autoria do filósofo francês Henry Lefebvre, que criticava as contradições existentes nos espaços urbanos, causadas, via de regra, pelo modo de produção capitalista, o qual acabava por excluir parcela da população do acesso à cidade, de modo que este direito representaria justamente a liberdade, socialização, participação, apropriação da cidade por esses excluídos (CASIMIRO, 2017, p.86).

Nesta vertente, portanto, a expressão “direito à cidade" apresenta uma conotação filosóficapolítica, voltada para questões sociais relevantes, embora, como afirma Tavolari (2016), não implica necessariamente traduzir essa demanda em um direito estatal. Trata-se, portanto, de uma denominação com um aspecto simbólico relevantíssimo, especialmente para os movimentos urbanos

\footnotetext{
${ }^{8}$ Hoje em dia o MNRU é denominado Fórum Nacional da Reforma Urbana (FNRU).

${ }^{9}$ Composto por organizações não-governamentais, movimentos sociais por moradia, parlamentares e prefeitos progressista, associações de moradores e de profissionais, dentre outros, cuja agenda centrava-se no direito à moradia, relacionando, também, outros temas como acesso ao transporte público e ao trabalho à ideia de reforma urbana (CAFRUNE, 2016).
} 
da América Latina, como no caso do MNRU, que adota, entre suas bandeiras, esta ideia, compreendoa como a garantia do acesso aos serviços e equipamentos urbanos, e a condições de vida digna nas urbes (CAFRUNE, 2016).

Nesta perspectiva, durante o período de tramitação do Estatuto da Cidade, especialmente no decorrer dos anos de 1990, conferências internacionais como a Rio-92 e a Habitat II, além da Conferência Nacional das Cidades, destacaram a importância da conexão entre direitos humanos, meio ambiente e sustentabilidade, causando impactos na concepção de direito à cidade presente no referido projeto de lei, que acabou recebendo a denominação final de "direito a cidades sustentáveis ${ }^{10 "}$ (SAULE JÚNIOR, 2018, online), o que faz do Brasil um dos únicos países do mundo a positivar este direito em instrumentos normativos cogentes (ALFONSIN et al., 2017).

Aqui, é relevante trazer o fato de que o debate acerca da dimensão jurídica do direito à cidade/direito a cidades sustentáveis ${ }^{11}$ ainda encontra-se em aberto no país, sendo um conceito em disputa (DUNDA, 2020, p.266). Parte-se, muitas vezes, da concepção sociológica/filosófica de autores como Lefebvre e Harvey como marcadores interpretativos da normatividade jurídica deste direito ${ }^{12}$ (DUNDA, 2020, p.266-267), o que, para fins deste trabalho, entende-se não ser a melhor leitura para a compreensão do direito a cidades sustentáveis, previsto no Estatuto da Cidade.

Não negando a forte influência da concepção sociológica/filosófica na criação da norma prevista no art.2º I, da Lei 10.257/2001, faz-se necessária a divisão do direito à cidade na concepção Lefebvriana/filosófica do direito a cidades sustentáveis positivado no Estatuto da Cidade. Esta divisão visa, justamente, gerar um melhor delineamento normativo do referido dispositivo legal, pois, como demonstrado, além da ideia de direito à cidade, em sua origem, não ser remetida a um direito estatal, a formulação de cidades sustentáveis e direito a cidades sustentáveis, no Brasil, sofreu inúmeras outras influências, como a de agendas e conferências internacionais, tal qual a Agenda 21, a Agenda Habitat, e a Conferência da Sociedade Civil Sobre Meio Ambiente e Desenvolvimento (SAULE JÚNIOR; LIBÓRIO, 2021, p.475-477).

\footnotetext{
${ }^{10}$ Ressalte-se que a ideia de sustentabilidade ambiental estava presente nos dois lados do debate na aprovação do Estatuto da Cidade, havendo uma superação do ranço e assimilação da responsabilidade ambiental por parte dos setores empresariais, e uma mudança de visão por parte dos movimentos pró-moradia, que tinham o referido discurso acerca da sustentabilidade como conservador e contrário aos seus interesses (BASSUL, 2004. p.139).

${ }^{11}$ Vários autores, como Saule Júnior e Libório (2021), utilizam o ter direito à cidade quando se referem ao dispositivo do art.2o, I, do Estatuto da Cidade.

${ }^{12}$ Exemplos desta abordagem podem ser encontrados nos trabalhos de Bodnar e Albino (2020), e Bianchi, Bodnar e Gonçalves Júnior (2021).
} 
Exposta a questão acima, importa dizer que este direito está expressamente positivado, na ordem jurídica brasileira, no art. $2 \stackrel{\circ}{\circ}, \mathrm{I}$, do Estatuto da Cidade, o qual afirma que o direito a cidades sustentáveis deve ser entendido como o direito à moradia, terra urbana, saneamento ambiental, transporte, serviços públicos, infraestrutura urbana, trabalho e ao lazer, para as gerações atuais e futuras, sendo, assim, uma diretriz geral da política urbana brasileira.

A mera leitura do texto legal já esclarece alguns pontos, como o fato de o direito a cidades sustentáveis ser um direito síntese, que abarca uma série de outros direitos, os quais, em boa parte, têm forte viés social e prestacional, como o direito à moradia, infraestrutura urbana, direito a terra e lazer, reforçando a ideia há pouco tratada de que o termo legal "cidades sustentáveis" não estaria necessariamente vinculado, de maneira intensa, apenas a questões econômicas e ambientais.

Neste ponto, é possível também defender que o direito a cidades sustentáveis, apesar de expressamente previsto e positivado no Estatuto da Cidade, é derivado e fundamentado em vários princípios constitucionais, sendo um verdadeiro direito fundamental material, decorrente da cláusula de abertura prevista no art. 5으, $§ 2^{\circ}$, da Constituição Federal, que prevê: "[...] os direitos e garantias expressos nesta Constituição não excluem outros decorrentes do regime e dos princípios por ela adotados, ou dos tratados internacionais em que a República Federativa do Brasil seja parte" (BRASIL, 1988 , online).

Esta cláusula de abertura, segundo Sarlet (2007, p. 98), traz a possibilidade de construção e identificação de direitos constitucionais que não estão positivados expressamente, assim como direitos fundamentais localizados em outras partes da Constituição e em tratados internacionais, não se restringindo, desta forma, ao rol dos direitos fundamentais às normas previstas no art. 5o da Constituição.

Do mesmo modo, a publicação Estatuto da Cidade: Guia para implementação pelos municípios e cidadãos (BRASIL et al., 2002, p. 32), da Câmara dos Deputados, dispõe ser o direito a cidades sustentáveis um novo direito fundamental, advindo das normas constitucionais da política urbana, funções sociais da cidade e da propriedade, sendo o seu exercício fundamental para viver em uma cidade social e ambientalmente saudável.

Já Saule Jr. (2007, p. 51-52) afirma que a fundamentalidade do direito a cidades sustentáveis decorre do princípio constitucional das funções sociais da cidade, havendo uma clara conexão entre a necessidade das cidades cumprirem suas funções sociais e sua população exercer o direito a cidades sustentáveis, "[...] uma vez que o objetivo é o mesmo de as pessoas terem um padrão de vida digna 
mediante o acesso a uma moradia adequada, ao trabalho, e ao lazer e de a cidade ter um meio ambiente ecologicamente equilibrado e sustentável" (SAULE JR., 2007, p. 52).

A fundamentação do direito a cidades sustentáveis, entretanto, não está restrita apenas aos artigos citados. Como expõe De Marco (2014, p. 331), este direito é um princípio constitucional, derivado da função social da propriedade, direito ao desenvolvimento urbano com garantia ao bemestar e direito ao meio ambiente ecologicamente equilibrado.

Seguindo estes entendimentos, compreende-se o direito a cidades sustentáveis como decorrente dos arts. 5ㅇ, XXII e XXIII' ${ }^{13}$; art. 170, III e VI ${ }^{14}$; art. $182^{15}$ e art. $225^{16}$ da Constituição, sendo, portanto, um direito materialmente fundamental ${ }^{1718}$, cuja menção expressa encontra-se no art. $2^{\circ}=$, I, do Estatuto da Cidade.

Quanto a sua classificação, o direito a cidades sustentáveis é, como informa Moreira (2006, p. 186), um direito difuso, estando no mesmo patamar do direito ao consumidor, direito ao meio

\footnotetext{
${ }^{13}$ Art. 5 o Todos são iguais perante a lei, sem distinção de qualquer natureza, garantindo-se aos brasileiros e aos estrangeiros residentes no País a inviolabilidade do direito à vida, à liberdade, à igualdade, à segurança e à propriedade, nos termos seguintes: (...)XXII - é garantido o direito de propriedade; XXIII - a propriedade atenderá a sua função social (BRASIL, 1988, online).

14 Art. 170. A ordem econômica, fundada na valorização do trabalho humano e na livre iniciativa, tem por fim assegurar a todos existência digna, conforme os ditames da justiça social, observados os seguintes princípios: (...)III - função social da propriedade; (...)VI - defesa do meio ambiente, inclusive mediante tratamento diferenciado conforme o impacto ambiental dos produtos e serviços e de seus processos de elaboração e prestação (BRASIL, 1988, online).

${ }^{15}$ Art. 182. A política de desenvolvimento urbano, executada pelo Poder Público municipal, conforme diretrizes gerais fixadas em lei, tem por objetivo ordenar o pleno desenvolvimento das funções sociais da cidade e garantir o bem- estar de seus habitantes (BRASIL, 1988, online).

16 Art. 225. Todos têm direito ao meio ambiente ecologicamente equilibrado, bem de uso comum do povo e essencial à sadia qualidade de vida, impondo-se ao Poder Público e à coletividade o dever de defendê-lo e preservá- lo para as presentes e futuras gerações (BRASIL, 1988, online).

${ }^{17}$ Apesar de não ser objetivo deste trabalho, calha lembrar que, pelo fato de ser um direito fundamental, é aplicado ao direito a cidades sustentáveis a norma do art. 5ㅇ, $\S 1$, , da Constituição (aplicabilidade imediata dos direitos fundamentais), assim como há dever de maximização de seus efeitos, além da necessidade de prestações positivas e ações negativas por parte do Estado e dos particulares para sua melhor efetivação.

${ }^{18}$ Infelizmente, o Judiciário ainda não se manifestou de maneira mais efetiva sobre a fundamentalidade do direito a cidades sustentáveis, havendo poucas referências neste sentido, como no caso da decisão monocrática proferida pelo desembargador federal Souza Prudente (TRF1), no agravo de instrumento n.o 005872844.2015.4.01.0000, publicado em 11 de março de 2016, onde, em obter dictum, é tratado como um direito fundamental. Aliás, em relação ao Judiciário e sua relação com o direito urbanístico/políticas urbanas, interessante estudo foi realizado por Rocha et al. (2016). Nele foi realizada pesquisa referente a termos utilizados no direito urbanístico, como "direito à cidade", no Tribunal de Justiça do Rio Grande do Sul, e acabou por concluir que a "[...] nova ordem jurídico-urbanística brasileira ainda tem um largo caminho a percorrer até vir a ser reconhecida, judicializada e efetivamente aplicada nas trincheiras do Poder Judiciário", pois o paradigma civilista ainda é mais forte que o urbanístico. Apesar de esta pesquisa ter sido restrita a apenas um tribunal de justiça, parece razoável pensar ser essa a regra no Judiciário brasileiro.
} 
ambiente etc. (SAULE JR., 2007, p. 30). Isso deriva de sua própria redação, ao garantir esse direito para às presentes e futuras gerações, denotando seu caráter transindividual, intergeracional e indeterminável. Também se trata de um direito fundamental de terceira dimensão, em terminologia utilizada por Bonavides (2008, p. 569), por seu alto teor de humanismo e por não ter como destinatário apenas um indivíduo, mas toda uma universalidade de pessoas, assim como os direitos ao meio ambiente e ao desenvolvimento.

No que se refere ao seu conteúdo normativo, o art. 2으, I, do Estatuto da Cidade, dispõe que o direito à cidade sustentável é entendido como o "[...] direito à terra urbana, à moradia, ao saneamento ambiental, à infra-estrutura urbana, ao transporte e aos serviços públicos, ao trabalho e ao lazer, para as presentes e futuras gerações". Entretanto, esse texto merece uma análise um pouco mais elaborada, com fito de encontrar o real significado da norma dele advinda.

Não restam dúvidas de que os direitos expressamente referenciados são integrantes do conteúdo normativo do direito a cidades sustentáveis, no entanto eles não são os únicos presentes na substância do referido direito, pois, como dito, ele é fundamentado em normas constitucionais, apesar de sua positivação estar em instrumento infraconstitucional, além de outros aspectos poderem ser retirados de uma melhor compreensão de seu texto.

Essa ideia de ampliação do conteúdo jurídico do direito a cidades sustentáveis em relação ao seu texto não é uma novidade. De Marco (2014, p. 333-366), por exemplo, afirma que o rol do art. 2으, I, do Estatuto da Cidade, é meramente exemplificativo, com o núcleo infraconstitucional deste direto sendo formado pelos direitos à terra urbana, à moradia, ao saneamento ambiental, à infraestrutura urbana, ao transporte e aos serviços públicos, ao trabalho, ao lazer e à gestão democrática da cidade, devendo, entretanto, serem incluídos quaisquer outros direitos urbanísticos que sejam essenciais à sustentabilidade dos centros urbanos para às presentes e futuras gerações.

Saule Jr. (2007, p. 52-53), por sua vez, afirma que os demais elementos para a satisfação do direito a cidades sustentáveis são encontrados tendo por base as funções sociais da cidade, de forma que a gestão democrática da cidade, o desenvolvimento das cidades sustentáveis e o direito cultural dos habitantes e das comunidades de preservar sua memória história e identidade também integrariam o núcleo do direito a cidades sustentáveis.

Já Mello (2017, p. 448), por exemplo, afirma que os elementos normativos do direito a cidades sustentáveis seriam os seguintes direitos: à moradia; aos serviços públicos adequados; à gestão democrática da cidade; à mobilidade urbana; ao planejamento urbano; à proteção do patrimônio histórico, artístico, cultural e paisagístico da cidade; à proteção do meio ambiente no 
espaço urbano; ao saneamento básico; ao lazer. Apesar de haver autonomia conceitual em cada um desses direitos, podendo ser tutelados individualmente, eles convergiriam para a formação do direito coletivo à cidade (MELLO, 2017, p. 448).

Este último ponto, inclusive, é de extrema importância para a compreensão do direito a cidades sustentáveis/direito à cidade como fenômeno jurídico. Não faria sentido ele ser considerado meramente como um somatório de direitos individuais urbanos, o que geraria, até mesmo, a desnecessidade de sua existência e positivação (SAULE JÚNIOR; LIBÓRIO, 2021, p.1485-1486; MELLO, 2017, p.447). Deve, portanto, ser entendido em sua dimensão difusa, como fomentador do pleno desenvolvimento das funções sociais da cidade.

Assim, levando-se em conta o acima exposto, adota-se uma visão ampliada do conteúdo normativo do direito a cidades sustentáveis, no seguinte sentido:

De início, é necessário destacar duas expressões constantes no texto do art.2ํㅡ, I, do Estatuto da Cidade, sendo a primeira, a própria nomenclatura da norma, direito a cidades sustentáveis, e, a segunda, a presença marcante dos princípios da equidade intra e intergeracional na passagem "para as futuras e presentes gerações".

Como já referido, o conceito de sustentabilidade tem forte vinculação à questão ambiental e à preservação dos limites ecológicos. Da mesma forma, a noção de solidariedade ou equidade intergeracional, conforme dispõe Marques (2012, p. 39), pressupõe a noção de manutenção dos recursos naturais para as gerações futuras, havendo estreita relação com o princípio da precaução. Além disso, há relação próxima entre o direito ao meio ambiente ecologicamente equilibrado (essencial à sadia qualidade de vida ${ }^{19}$ ) e a disposição sobre política urbana referente ao bem-estar da população - ambas são normas que fundamentam o direito a cidades sustentáveis, de forma que a proteção do meio ambiente (em todas as suas formas, ou seja, artificial, cultural, natural e do trabalho) também faz parte do conteúdo jurídico do referido direito, devendo ser o seu fio condutor.

Quanto à equidade intergeracional, pode-se dizer que, em decorrência do caráter difuso do direito a cidades sustentáveis, ela se expressa, especialmente, no princípio/direito à justa distribuição dos benefícios e ônus do processo de urbanização, presente no art.2ำ, IX, do Estatuto da Cidade. Esta norma orienta para um equilíbrio nas propostas de transformação da cidade, sendo ilícito "atribuir

\footnotetext{
${ }^{19}$ Neste ponto, Belchior e Matias (2007, p.173) afirmam que o direito a um meio ambiente equilibrado e à sadia qualidade de vida está relacionado, também, aos aspectos físicos e espirituais, sendo necessárias normas que incentivem práticas econômicas socialmente justas e que protejam o meio ambiente.
} 
ônus e distribuir benefícios somente para alguns setores da comunidade" (CARVALHO FILHO, 2009, p.40).

A participação democrática, por seu turno, também é de fundamental importância para a formação do direito a cidades sustentáveis. Segundo Mello (2017, p. 453), a gestão da cidade moderna pressupõe a participação popular, pois os habitantes têm o direito de serem tratados como iguais no processo de formação de decisões que afetem toda a comunidade. Se a política de desenvolvimento urbano visa o bem-estar da população, a participação desta naquele processo é fundamental.

Neste sentido, Gollagher e Hartz-Karp (2013, p. 2360-2361) afirmam que a desconexão entre as instituições governamentais, que muitas vezes não dialogam entre si, e a falta de colaboração entre governo, comunidade, ONGs e instituições privadas são grandes barreiras para a construção de cidades sustentáveis, sugerindo, assim, um misto entre democracia deliberativa e governança colaborativa como forma de contribuir mais efetivamente para o alcance da sustentabilidade.

O próprio ordenamento jurídico brasileiro garante a gestão democrática da cidade, em capítulo próprio no Estatuto da Cidade, o qual prevê várias formas de participação dos habitantes nos rumos das urbes, sendo, inclusive, nos termos do art. 40 da Lei n.o 10.257, uma exigência na elaboração, implementação e fiscalização do plano diretor das cidades. Para que haja a efetiva participação popular, é necessário o acesso às informações relativas aos procedimentos a serem adotados e suas consequências, direito também garantido pelo Estatuto da Cidade. Assim, a gestão democrática da cidade também é parte do conteúdo normativo do direito a cidades sustentáveis.

Assim, chega-se à conclusão que o direito a cidades sustentáveis apresenta um conteúdo normativo mais amplo que o disposto em seu texto legal, positivado no Estatuto da Cidade, abarcando questões como o direito à proteção do meio ambiente em todas as suas formas, inclusive o cultural, com a necessidade de proteção do patrimônio histórico material e imaterial; justa distribuição dos benefícios e ônus do processo de urbanização, e o direito à gestão democrática da cidade, os quais devem ser desenvolvidos de forma integrada e tomando-se por base uma concepção difusa, que tem por fio condutor a ideia de sustentabilidade.

Este seria, portanto, o conteúdo mínimo do direito a cidades sustentáveis, sendo importante lembrar que cada centro urbano é diferente do outro e, na busca de seu desenvolvimento urbano sustentável, pode necessitar da implementação de tantos outros direitos. Além disso, relevante ressaltar que a própria realização deste conteúdo jurídico mínimo do direito a cidades sustentáveis faz supor a necessidade de aportes financeiros por parte do Estado e dos particulares, de modo que é 
necessário, também, que os centros urbanos e seus moradores tenham um sistema econômico equilibrado e sustentável.

É também importante lembrar que, desde sua formulação no Estatuto da Cidade, o direito a cidades sustentáveis recebeu influência de agendas internacionais, de forma que, estas, também ajudam a compreender melhor e a densificar o conteúdo jurídico deste fenômeno, levando em especial consideração os instrumentos internacionais firmados pelo Brasil, como o caso dos ODS e da Nova Agenda Urbana.

Farias e Correia (2021, p.84-85), neste sentido, afirmam que a concepção de cidades sustentáveis no ordenamento jurídico nacional leva a encampação das discussões acerca do desenvolvimento sustentável, onde a cidade passa a ser um bem urbano-ambiental, havendo a necessidade de harmonizar os art.182 e 183 da Constituição com o art.225 do mesmo diploma, o que estabelece, assim, um diálogo com o ODS-11 e a Nova Agenda Urbana.

Em que pese sejam instrumentos de soft law, ou seja, não possuem força cogente, podem certamente servir para densificar o direito nacional e influenciar a criação de políticas públicas, dependendo do nível de comprometimento de cada Estado (GARSCHAGEN et al., 2018, p.122-123). Isto, inclusive, já ocorreu no Brasil, como informam Motta, Jatobá e Ribeiro (2009, p.108-109), com a Agenda Habitat servindo de influência para técnicos e administradores municipais na elaboração de projetos, planos e políticas de desenvolvimento urbano.

Assim, entende-se ser possível utilização desses instrumentos internacionais e de seus indicadores para densificar e esclarecer o conteúdo do direito a cidades sustentáveis, especialmente em relação a aspectos como mobilidade urbana, proteção ambiental, economia urbana e habitação. Esta aplicação, no entanto, deve ser feita de maneira contextualizada, respeitando as particularidades locais, direcionamento já proposto, inclusive, pela ONU em relação aos ODS, tendo o ODS-11 como eixo central deste processo (GLOBAL TASKFORCE OF LOCAL AND REGIONAL GOVERNMENTS et al., 2016, P.12-13). Desta forma, é aceitável a utilização dos indicadores destes documentos, desde que devidamente contextualizados, como forma de melhor compreensão do fenômeno da dimensão jurídica das cidades sustentáveis no Brasil.

Resta, por fim, dizer que os direitos que conformam o direito a cidades sustentáveis podem se chocar, como demonstrado, por exemplo, no caso do programa Minha Casa Minha Vida, cujo objetivo principal era garantir o direito à moradia, mas acabou gerando espraiamento indesejável, causando déficit de infraestrutura urbana, serviços públicos e dificuldades de circulação para boa parte dos aderentes (CEPESP; INSTITUTO ESCOLHAS, 2019). Desta forma, na implementação desses direitos 
deve haver integração de políticas, buscando equilibrá-los/compatibilizá-los e, em último caso, utilizarse da regra da proporcionalidade (MATIAS; MATTEI, 2019).

Tem-se, portanto, uma leitura mais concisa do direito a cidades sustentáveis, verdadeiro princípio motriz da política de desenvolvimento urbano do país, e que, por isso, deve ser devidamente realizado. Sua implementação é uma forma de racionalizar o planejamento das urbes brasileiras, tendo por base a noção de sustentabilidade e focando no bem-estar da população, garantindo a equidade intra e intergeracional.

Sabe-se que esta não é uma tarefa fácil, sendo necessários muitos estudos, vontade política e recursos financeiros, mas, certamente, o primeiro passo para que este direito saia do papel é a sua melhor compreensão.

\section{CONCLUSÃO}

O conceito de cidades sustentáveis é vital para que sejam implementadas políticas de mitigação do crescimento urbano desordenado. Não há dúvida de que indicadores firmados em documentos internacionais influenciam a conformação do conceito, desde que devidamente contextualizados de acordo com as realidades locais.

Conclui-se, então, que cidades sustentáveis são aquelas que promovem atividades econômicas produtivas e são social e politicamente inclusivas, assim como, ambientalmente sustentáveis, característica que baseia e conforma as demais. Trata-se de um conceito amplo, justamente para dar margem a adaptações às especificidades locais na busca pelo desenvolvimento urbano sustentável, visto a grande diferença existente entre os centros urbanos e entre suas necessidades e prioridades, havendo, contudo, um fio condutor na figura do respeito à integridade ecológica/sustentabilidade.

A ordem jurídica brasileira acolhe o conceito de direito a cidades sustentáveis, apresentando um conteúdo normativo mais amplo que o disposto em seu texto legal, positivado no Estatuto da Cidade, abarcando questões como proteção ao meio ambiente em todas as suas formas, inclusive cultural, com a necessidade de proteção do patrimônio histórico material e imaterial, justa distribuição dos benefícios e ônus do processo de urbanização, e, ainda, gestão democrática da cidade, todos devidamente integrados, apresentando, também, um marcante viés social e difuso. Trate-se de um verdadeiro direito fundamental de terceira dimensão, decorrente da cláusula de abertura do art. 5ㅇ, $\S 2$ o da Constituição Federal. 
O modelo de desenvolvimento da política urbana brasileira é, portanto, o modelo do desenvolvimento urbano sustentável, fato que traz duas consequências principais: a política urbana não se limita a ordenar espacialmente as cidades através de seus instrumentos, mas deve, sim, integrar-se com as políticas sociais, econômicas e ambientais na busca pela melhoria da qualidade de vida dos habitantes; e a necessidade de garantir a participação dos cidadãos em todas as fases do planejamento urbano, em sintonia com indicadores de sustentabilidade urbana consagrados.

Desta forma, a melhor compreensão do fenômeno do direito a cidade sustentável é o primeiro passo para sua implementação, que tem por finalidade racionalizar o processo de planejamento urbano nacional em prol do bem-estar da população e da garantia da equidade intra e intergeracional.

\section{REFERÊNCIAS}

ACSELRAD, Henri. Discursos da sustentabilidade urbana. Revista Brasileira de Estudos Urbanos e Regionais, Rio de Janeiro, n. 1, p. 79-90, 1999. DOI: 10.22296/2317-1529.1999n1p79.

ALFONSIN, Betânia; ROCHA, Aline Alves; AMIN, Luisa Almeida; CORTESE, Vicente de Azevedo Bastian; BERTHOLD, Stéfanie; PEREIRA, Pedro Prazeres Fraga; GOLDENFUM, Fernanda Peixoto. A ordem jurídico-urbanística nas trincheiras do Poder Judiciário / The legal-urban order in the judicial trenches. Revista Direito e Práxis, Rio de Janeiro, v. 7, n. 14, 2016. DOI: 10.12957/dep.2016.22951.

, Betânia De Moraes; SALTZ, Alexandre; FACCENDA, Guilherme; VIVAN FILHO, Gerson Tadeu Astolfi; MULLER, Renata; FERNANDEZ, Daniel. Das ruas de Paris a Quito: o direito à cidade na Nova Agenda Urbana - HABITAT III. Revista de Direito da Cidade, Rio de Janeiro, v. 9, n. 3, p. 1214-1246, 2017. DOI: $10.12957 /$ rdc.2017.29236.

BARRAL, Virginie. Sustainable development in international law: Nature ; and operation of an evolutive legal norm. European Journal of International Law, [S. I.], v. 23, n. 2, p. 377-400, 2012. DOI: $10.1093 /$ ejil/chs016.

BASSUL, José Roberto. Estatuto da Cidade: Quem ganhou ? Quem perdeu ? Brasília.

BIANCHI, Patricia Nunes Lima; BODNAR, Zenildo; GONÇALVES JUNIOR, Luiz Claudio. O direito da cidade: entre a segregação socioespacial e a busca por cidades sustentáveis. Revista de Direito da Cidade, Rio de Janeiro, v. 13, n. 3, p. 1269-1291, 2021. DOI: 10.12957/rdc.2021.51380.

BODNAR, Zenildo; ALBINO, Priscilla Linhares. As múltiplas dimensões do direito fundamental à cidade. Revista Brasileira de Políticas Públicas, Brasília, v. 10, n. 03, 2020.

BONAVIDES, Paulo. Curso de Direito Constitucional. 22. ed. São Paulo: Malheiros Editores, 2008.

BOSSELMANN, Klaus. Princípio da Sustentabilidade: Transformando Direito e Governança. 1. ed. São Paulo: Revista dos Tribunais, 2015. 
BRASIL. Constituição (1988). Constituição da República Federativa do Brasil, Brasília, DF, Senado, 1988. Disponível em: http://www.planalto.gov.br/ccivil_03/constituicao/constituicao.htm. Acesso em: 02 de mar. de 2020.

. Lei no 10.257, de 10 de julho de 2001. Regulamenta os arts.182 e 183 da Constituição Federal, estabelece diretrizes gerais da política urbana e dá outras providências. Diário Oficial da União, Brasília, DF, 11 de julho de 2001. Disponível em:

http://www.planalto.gov.br/ccivil_03/leis/leis_2001/l10257.htm. Acesso em: 02 de mar. de 2020.

Projeto de Lei no 5.788, de 1990. Estabelece Diretrizes Gerais de Política Urbana e Dá Outras Providências. Diário Oficial da União, Brasília, DF, 10 de outubro de 1990. Disponível em: http://imagem.camara.gov.br/Imagem/d/pdf/DCD100UT1990.pdf\#page=97. Acesso em: 10 de jun. de 2021.

; CÂMARA DOS DEPUTADOS, CEDI - Centro de Documentação e Informação; POLIS - Instituto Polis. 2002. Estatuto da Cidade - guia para implementação pelos municípios e cidadãos. Brasília: Câmara dos Deputados, Centro de Documentação e Informação - CEDI, Coordenação de Publicações - CODEP.

CAFRUNE, Marcelo Eibs. O direito à cidade no Brasil: construção teórica, reivindicação e exercício de direitos. Revista Interdisciplinar de Direitos Humanos - UNESP, Bauru, v. 4, n. 16, p. 185-206, 2016.

CARADONNA, Jeremy L. Sustainability: A History. Oxford: Oxford University Press, 2014.

CARVALHO FILHO, José dos Santos. Comentários ao Estatuto da Cidade. $3^{\mathrm{a}}$ ed. Rio de Janeiro: Editora Lumen Juris, 2009.

CASIMIRO, Ligia Maria Silva Melo De. Planejamento Social e Mobilidade Urbana Como

Fundamentos do Direito à Cidade no Brasil. 2017. Pontifícia Universidade Católica do Paraná, Curitiba, 2017. DOI: 10.1002/ejsp.2570. Disponível em:

http://www.tandfonline.com/doi/abs/10.1080/14639947.2011.564813\%0Ahttp://dx.doi.org/10.108 0/15426432.2015.1080605\%0Ahttps://doi.org/10.1080/15426432.2015.1080605\%0Ahttp://heinonli ne.org/HOL/Page?handle=hein.journals/abaj102\&div=144\&start_page=26\&collectio.

CEPESP, INSTITUTO ESCOLHAS. MORAR LONGE : o Programa Minha Casa Minha Vida e a expansão das Regiões Metropolitanas. São Paulo, 2019.

COMISSÃO MUNDIAL SOBRE MEIO AMBIENTE E DESENVOLVIMENTO. Nosso Futuro Comum. $2^{\mathrm{a}}$ ed. Rio de Janeiro: Fundação Getúlio Vargas, 1991.

COSTA, Heloisa Soares de Moura. Desenvolvimento Urbano Sustentável: Uma Contradição de Termos? Revista Brasileira de Estudos Urbanos e Regionais, Rio de Janeiro, n. 2, 1999.

DE MARCO, Christian Magnus. O Direito Fundamental à Cidade Sustentável. Saarbrucken: Novas Edições Acadêmicas, 2014.

DUNDA, Maria Virginia Faro Eloy. O Direito à Cidade em Construção Dentro do Ordenamento Urbanístico Brasileiro: Análise do debate acadêmico de 2001 a 2018. 2020. Universidade Católica de Pernambuco, Recife, 2020. DOI: 10.13140/RG.2.2.35077.88800. 
EUROPEAN COMMISSIONS DG ENVIRONMENT BY THE SCIENCE COMMUNICATION UNIT. In-depth Report: Indicators for Sustainable Cities. Bristol. 2018. DOI: 10.2779/121865. FARIAS, Talden; CORREIA, Arícia Fernandes. Considerações Sobre o Estatuto da Cidade: Balanços e Desafios. In: 20 Anos de Estatuto da Cidade: Experiências e Reflexões. Belo Horizonte: Gaia Cultural - Cultura e Meio Ambiente, 2021.

FREITAS, Juarez. Sustentabilidade: Direito ao Futuro. $3^{\text {a }}$ ed. Belo Horizonte: Editora Fórum, 2016.

GARSCHAGEN, Matthias et al. The New Urban Agenda: From Vision to Policy and Action/Will the New Urban Agenda Have Any Positive Influence onGovernments and International Agencies?/Informality in the New Urban Agenda: From the Aspirational Policiesof Integration to a Politics of Const. Planning Theory and Practice, [S. I.], v. 19, n. 1, p. 117-137, 2018. DOI: 10.1080/14649357.2018.1412678. Disponível em: http://doi.org/10.1080/14649357.2018.1412678.

GLOBAL TASKFORCE OF LOCAL AND REGIONAL GOVERNMENTS; UN-HABITAT; PROGRAMA DAS NAÇÕES UNIDAS PARA O DESENVOLVIMENTO - PNUD; ONU-BR. Roteiro Para Localização dos Objetivos de Desenvolvimento Sustentável: Implementação e Acompanhamento no Nível Subnacional. [s.l: s.n.].

GOLLAGHER, Margaret; HARTZ-KARP, Janette. The role of deliberative collaborative governance in achieving sustainable cities. Sustainability (Switzerland), [S. I.], v. 5, n. 6, p. 2343-2366, 2013. DOI: $10.3390 /$ su5062343.

10.12957/rdc.2021.43832.

INSTITUTO BRASILEIRO DE PESQUISA ECONÔMICA APLICADA (Ipea). Relatório Brasileiro para o Habitat III. Brasília: ConCidades, Ipea, 2016.

Indicadores Brasileiros - Habitat III. Disponível em: http://www.participa.br/habitat/habitat-iiiparticipa-brasil/indicadores/indicadores-brasileiros-habitat-iii. Acesso em: 15 jun. 2019.

KAIKA, Maria. 'Don't call me resilient again!': the New Urban Agenda as immunology ... or ... what happens when communities refuse to be vaccinated with 'smart cities' and indicators. Environment and Urbanization, [S. I.], v. 29, n. 1, p. 89-102, 2017. DOI: 10.1177/0956247816684763.

LEFF, Enrique. Saber Ambiental: Sustentabilidade, Racionalidade, Complexidade, Poder. $4^{\mathrm{a}}$ ed. Petrópolis: Editora Vozes, 2005.

LIMONAD, Ester. Natureza da" ambientalização" do discurso do planejamento. Scripta Nova: revista electrónica de geograf́la y ciencias sociales, Barcelona, v. XIV, n. 331 (66), 2010.

MARQUES, Clarissa. Meio Ambiente, Solidariedade E Futuras Gerações. Nomos, Fortaleza, v. 32, n. 2, p. 37-56, 2012. Disponível em: http://periodicos.ufc.br/index.php/nomos/article/view/350.

MATIAS, João Luis Nogueira; BELCHIOR, Germana. Direito, Economia E Meio Ambiente: a Função Promocional Da Ordem Jurídica E O Incentivo a Condutas Ambientalmente Desejadas. Nomos, Fortaleza, v. 27, n. 0, p. 155-176, 2007.

MATTEI, Julia; MATIAS, João Luis Nogueira. A efetivação da nova ordem urbanística pelo Poder 
Judiciário: análise das decisões proferidas pelo Tribunal de Justiça do Estado do Ceará, oriundas da comarca de Fortaleza entre 2013 e 2017. Revista de Direito da Cidade, Rio de Janeiro, v. 11, n. 3, p. 471-495, 2019. DOI: 10.12957/rdc.2019.39574.

MELLO, Cláudio Ari. Elementos para uma teoria jurídica do direito à cidade. Revista de Direito da Cidade, Rio de Janeiro, v. 9, n. 2, p. 437-462, 2017. DOI: 10.12957/rdc.2017.26883.

MOREIRA, Danielle de Andrade. O direito a cidade sustentáveis. Revista de Direito da Cidade, Rio de Janeiro, v. 06, n. 02, p. 179-200, 2006.

MOTTA, Diana Meirelles Da; JATOBÁ, Sérgio Ulisses Silva; RIBEIRO, Rômulo. A CF/88 e o Desenvolvimento Urbano. In: A Constituição Brasileira de 1988 Revisitada: Recuperação Histórica e Desafios Atuais das Políticas Públicas nas Áreas Regional, Urbana e Ambiental. Brasília: Ipea, 2009. p. 91-116.

ONU-HABITAT. Nova Agenda Urbana. 2016.

ORGANIZAÇÃO DAS NAÇÕES UNIDAS. Goal 11: Make Cities Inclusive, Safe, Resilient and Sustainable. Disponível em: https://www.un.org/sustainabledevelopment/cities/. Acesso em: 11 de fev. 2020.

Declaração de Estocolmo Sobre Meio Ambiente e Desenvolvimento. 1972. Disponível em: http://www.direitoshumanos.usp.br/index.php/Meio-Ambiente/declaracao-de-estocolmo-sobre-oambiente-humano.html. Acesso em: 21 de fev. 2020.

PORRAS, IM. The City and International Law: In Pursuit of Sustainable Development. Fordham Urban Law Journal, Nova lorque, v. 36, n. 3, p. 537-601, 2009. DOI: 10.1525/sp.2007.54.1.23.

REES, William; Mathis Wackernagel. Urban Ecological Footprints: Why Cities Cannot Be Sustainable And Why They Are A Key to Sustainability. Environment Impact Assess Rev, [S. I.], v. 9255, n. 96, p. 223-248, 1996. DOI: 10.1016/S0195-9255(96)00022-4.

SACHS, Jeffrey D. A Era do Desenvolvimento Sustentável. kindle edi ed. Lisboa: Conjuntura Actual Editora, 2017.

SARLET, Ingo Wolfgang. A Eficácia dos Direitos Fundamentais. 9. ed. Porto Alegre: Livraria do Advogado, 2008.

SATTERTHWAITE, David. Sustainable cities or cities that contribute to...: EBSCOhost. Urban Studies, [S. I.], v. 34, n. 10, p. 1667-1691, 1997. Disponível em:

http://journals.sagepub.com/doi/pdf/10.1080/0042098975394\%0Ahttp://web.a.ebscohost.com/eho st/pdfviewer/pdfviewer?sid=453634cc-8e21-49e4-ab69-

9cdd30bc95b2\%40sessionmgr4001\&vid=1\&hid=4209.

SAULE JÚNIOR, Nelson. Interfaces do Direito à Cidade e Direito Urbanístico no Brasil e na Órbita Internacional. In: Direito Urbanístico: Vias Jurídicas das Políticas Urbanas. Porto Alegre: Sergio Antonio Fabris Editor, 2007. p. 27-186.

A cidade Como um Bem Comum: Pilar Emergente do Direito à Cidade. [s.l: s.n.]. Disponível em: https://terradedireitos.org.br/acervo/artigos/a-cidade-como-um-bem-comum-pilar-emergente- 
do-direito-a-cidade/22900.

; LIBÓRIO, Daniela Campos. Questões chaves da noção jurídica do direito à cidade. Revista de

Direito da Cidade, [S. I.], v. 13, n. 3, p. 1466-1494, 2021. DOI:

TAVOLARI, Bianca. Direito à cidade: uma trajetória conceitual. Novos Estudos - CEBRAP, São Paulo, v. 104, p. 93-109, 2016. Disponível em:

https://www.researchgate.net/publication/306056929_Direito_a_cidade_uma_trajetoria_conceitual

VEIGA, José Eli Da. Para Entender o Desenvolvimento Sustentável. São Paulo: Editora 34, 2015.

Sobre os autores:

João Luis Nogueira Matias

Doutor em Direito Comercial pela Universidade de São Paulo - USP (2009). Doutor em Direito público pela Universidade Federal de Pernambuco (2003). Mestre em Direito e desenvolvimento pela Universidade Federal do Ceará (1999). MBA em gestão de empresas FGV/MARPE (2005). Professor Associado, nível IV, da Universidade Federal do Ceará e do Centro Universitário 7 de Setembro - UNI7. Ministra as disciplinas "Direito da empresa I" (direito societário), "Ordem jurídica e economia na perspectiva dos direitos fundamentais" e "Meio ambiente, sustentabilidade e direitos fundamentais", respectivamente, na graduação e no Programa de Pós-graduação (Curso de Mestrado e Doutorado). Ex-coordenador do Programa de Pós-Graduação em Direito da UFC. Tem experiência na área de Direito, com ênfase em direito comercial, direito econômico e ambiental, focando seus estudos e trabalhos principalmente nos seguintes temas: direito da empresa, direito da propriedade, efetivação dos direitos fundamentais, relações entre direito e economia, direito ambiental e biodiversidade. Parecerista ad hoc da CAPES.

Universidade Federal do Ceará, Fortaleza, CE, Brasil

Lattes:http://lattes.cnpq.br/8192937377585273 Orcid: http://orcid.org/0000-0002-3873-702X

E-mail: joaoluisnm@uol.com.br

\section{Lucas Campos Jereissati}

Advogado, jornalista e mestre em Ordem Jurídica Constitucional pela Universidade Federal do Ceará Universidade Federal do Ceará, Fortaleza, CE, Brasil

Lattes:http://lattes.cnpq.br/1955937876650870 Orcid: https://orcid.org/0000-0002-7243-2684

E-mail: lucasverlaine@gmail.com

Os autores contribuíram igualmente para a redação do artigo. 